\title{
A educação como missão e o "problema indígena": a atuação de José Vasconcelos à frente da educação pública do México (1920-1924)
}

João Gabriel da Silva Ascenso ${ }^{1}$

Resumo: Em 1920, chegava ao fim uma década de guerra civil que assolara o México, durante a chamada "Revolução Mexicana". Em um contexto em que a legitimidade do governo, e da própria revolução, pautava-se em sua reivindicação em nome do povo, tornava-se necessária uma ação que criasse laços de pertencimento e identidade entre a população mexicana, guiando-a em direção ao progresso. A educação, então, desponta como foco privilegiado. Entre 1920 e 1924, José Vasconcelos esteve à frente da educação pública no México. Primeiro como reitor da Universidade Nacional e depois como secretário de educação, ele criou uma campanha de alfabetização que se tornaria célebre, fundou uma Secretaria de Educação Pública que teria, pela primeira vez, alcance nacional, e dedicou especial atenção às populações indígenas. Este trabalho pretende analisar o alcance concreto das medidas adotadas por Vasconcelos, bem como suas inspirações teóricas e filosóficas e, particularmente, o papel que atribuía ao indígena dentro daquilo que deveria ser a nação mexicana.

Palavras-chave: José Vasconcelos; educação; indígenas.

\section{The education as a mission and the "indigenous problem": José Vasconcelos heading the public education in Mexico (1920-1924)}

\begin{abstract}
In 1920, a decade of civil war in Mexico, during the "Mexican Revolution", was coming to an end. In a context in which the legitimacy of the government, as well as of the revolution itself, was based on the claim that they were made in the name of the people, it became necessary to create bonds of belonging and identity among the Mexican population, guiding it towards progress. The education, then, emerged as a privileged focus. Between 1920 and 1924, José Vasconcelos headed the public education in Mexico. First as the rector of the National University and later as secretary of education, he created a literacy campaign that would become famous, founded a Secretariat of Public Education that would, for the first time, reach national scope, and dedicated special attention to the indigenous populations. This paper aims to analyze the concrete scope of the measures adopted by Vasconcelos, as well as his theoretical and philosophical inspirations and, particularly, the role that he attributed to the indigenous peoples within what should be the Mexican nation.
\end{abstract}

Keywords: José Vasconcelos; education; indigenous.

Artigo recebido em: 15/07/2017

Artigo aprovado em: 18/11/2017

\footnotetext{
${ }^{1}$ Doutorando em História Social da Cultura pela PUC-Rio, mestre em História Social pela UFRJ 
La educación pública como esfuerzo organizado y sistemático se inicia en el continente americano con el trabajo de los misioneros católicos. La orden franciscana, pura de vigor y de fe; la orden dominicana, todavía no manchada de intransigencia; la orden jesuítica, más tarde y en una época en que todavía la sed de dominación no la perdía; he ahi a los precursores de todo lo que entre nosotros es cultura. [...] No vinieron a enseñar a leer y a escribir, ni vinieron a propagar un idioma, ni solamente una fe religiosa. La acción de estos maestros en el arte de educar abarcó todo lo ya mencionado y, todavía más, fue una acción social cuya transcendencia perdura. [...] Se les podría tomar como modelo para el fomento de la civilización en cualquier región de la Tierra, y entre nosotros no creo que sea posible ni atinada una labor educativa que no tome en cuenta el sistema de los misioneros, sistema cuyos resultados no sólo no se han podido superar, pero ni siquiera igualar.

(José Vasconcelos, “La educación pública”, Indología, 1926)

\section{Quetzalcóatl e a educação como missão}

A 04 de junho de 1920, o presidente interino do México, Adolfo de la Huerta, nomeou como reitor da Universidade Nacional do México um homem que se tornaria símbolo do esforço em prol de uma educação nacional, popular, revolucionária e mestiça. Pouco mais de um ano depois, já no governo de Álvaro Obregón, esse mesmo homem assumiria a recém-criada Secretaria de Educação Pública (SEP), em cargo que ocuparia de 1921 a 1924. Trata-se de José Vasconcelos Calderón, aclamado pela juventude latino-americana da geração da Reforma Universitária como maestro de la juventud, famoso ensaísta autor de La raza cósmica: misión de la raza iberoamericana, filósofo crítico do que chamava de "materialismo anglo-saxão" em nome dos dons do espírito e da beleza (que atribuía ao caráter latino de seu povo) e defensor apaixonado de uma identidade mestiça para o México.

Quando assumiu a reitoria da Universidade Nacional, o fez após o próprio governo anterior, de Venustiano Carranza, ter abolido a existência de um ministério (ou secretaria) federal voltado para a educação pública, baseando-se na ideia do "município livre", que conferia a cada município a responsabilidade pelo estabelecimento da educação (VASCONCELOS, 2009e, p. 11). Seu cargo como reitor, desta forma, agregava a função de gestor de um conjunto de instituições educativas e escolas profissionais - uma chefatura de departamento que, todavia reduzida em seu poder de

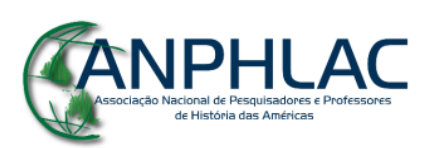

Revista Eletrônica da ANPHLAC, ISSN 1679-1061, №. 23, p. 82-118, Jul./Dez., 2017.

http://revista.anphlac.org.br 
atuação, constituía, ainda assim, na única instituição concernente ao que se poderia chamar de uma "educação nacional" no México.

No discurso que pronunciou por ocasião da sua tomada de posse como reitor, fez uma famosa proclamação: "En estos momentos yo no vengo a trabajar por la Universidad, sino a pedir a la Universidad que trabaje por el pueblo" (VASCONCELOS, 2009c, p. 141). Tornava-se patente a sua constatação de que a constituição elitista da universidade não servia à causa da educação nacional, mas o conhecimento por ela produzido poderia (e deveria) servir ao povo. ${ }^{2}$ Os anos de guerra civil (1910-1920) que marcaram a experiência da Revolução Mexicana legaram ao país uma exacerbação do discurso de cunho social. A Revolução seria feita pelo povo e para o povo, e toda a sua legitimidade repousava nesta prerrogativa. Os debates da Constituinte de 1917 nos mostram que falar em nome da ordem constitucional e da normalidade institucional não era mais suficiente. A palavra "povo" ganhara novos contornos e passara a significar, sobretudo, o camponês, o indígena, por vezes o trabalhador urbano e, cada vez mais, o mestiço - símbolo de uma nação popular (MONTFORT, 1999).

No segundo volume de sua autobiografia, La tormenta, Vasconcelos se recorda de um diálogo com o político e escritor Miguel Alessio Robles, antes de assumir a reitoria da Universidade, em que teria dito:

Créame, Miguel. Si me decido a la vida pública, si mis condiciones son aceptadas, no me dedicaré ni siquiera a la Universidad. Me dedicaré a reformar el criterio de la escuela primaria, en las clases de historia. Será preciso saltar una, dos generaciones, para que algo limpio y fuerte pueda salir de este pudridero. (VASCONCELOS, 1982b, p. 950)

\footnotetext{
${ }^{2}$ As reformas que Vasconcelos defendeu para a educação pública no início dos anos 1920 partiam de projetos muito semelhantes àqueles que Justo Sierra - secretário de instrução pública de Porfírio Díaz encampou, ou tentou encampar, entre 1901 e 1910: crítica ao utilitarismo na educação, urgência da federalização do ensino (como veremos mais à frente), ampliação da educação gratuita e obrigatória como forma de garantir ao povo o pleno acesso à democracia, reflexões sistemáticas sobre a educação rural e indígena, indissociabilidade entre a universidade e o retorno social do seu trabalho... De fato, Justo Sierra foi uma grande inspiração para Vasconcelos. Tais concepç̃os também foram a tônica do Ateneo de la Juventud, grupo do qual Vasconcelos fazia parte e para o qual a promoção de um resgate do humanismo de base hispânica como fundamento da cultura nacional não poderia vir desvinculada de uma ação social que levasse à população os meios de se emancipar política, econômica e espiritualmente. Carlos Monsiváis, em seu artigo "Notas sobre la cultura mexicana en el siglo XX", traz uma excelente discussão sobre a importância das discussões dos ateneístas no projeto de Vasconcelos (MONSIVÁIS, 1976).
}

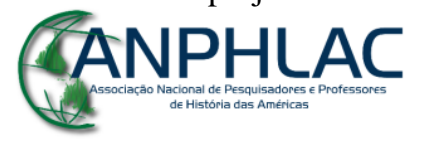

Revista Eletrônica da ANPHLAC, ISSN 1679-1061, №. 23, p. 82-118, Jul./Dez., 2017.

http://revista.anphlac.org.br 
Torna-se claro que o grande objetivo de Vasconcelos, ao aceitar, pouco tempo depois, o cargo de reitor, foi ter a possibilidade de intervir na educação pública de maneira geral, e em especial na escola primária. A ênfase nas classes de história se relaciona, como será visto, à própria direção que Vasconcelos enxergava na história do México, uma história que deveria ser de progresso se se aproveitasse o legado daqueles que lutaram para construir uma verdadeira civilização no país.

Mesmo que a Revolução se fizesse em nome do povo, o período revolucionário no México não fora acompanhado pelo desenvolvimento de uma política educativa como o fora na Revolução Russa, por exemplo -, quem sabe pelo medo, por parte dos dirigentes, de que as escolas se convertessem em "fábricas de zapatistas". Desta forma, segundo as estatísticas oficiais, em 1920, somente $4,93 \%$ da população mexicana se encontrava escolarizada, contra os 6,23\% de 1910, durante a gestão de Justo Sierra (FELL, 1989, p. 9).

Em 1920, tinha-se a chance de tentar reverter este quadro. Uma facção política específica conseguira chegar ao poder, com a ascensão do chamado "triângulo sonorense" - Adolfo de la Huerta, Álvaro Obregón e Plutarco Elías Calles -, em um contexto de desarticulação da oposição. Além disso, a economia mexicana atingia um período de crescimento e de relativa estabilidade, decorrente, sobretudo, das exportações de petróleo e de minérios (MEYER Jr., 2001, p. 197).

Ao mesmo tempo, os governos que assumiram o poder (primeiro o provisório, de De la Huerta, e posteriormente o regular, de Obregón), ainda que liderados por representantes da burguesia do Norte, sabiam que deveriam se legitimar enquanto governos verdadeiramente revolucionários, o que queria dizer governos atrelados aos anseios de igualdade e de justiça social que emergiram no processo da guerra civil, e que se materializaram no conjunto de garantias assegurado pela Constituição de 1917. Ou seja, pela primeira vez, a implementação de uma política educacional de larga escala era possível e, mais do que isso, era extremamente necessária para a construção de uma unidade nacional em um país dividido por uma década de luta fratricida, pelo caráter regionalizado das elites políticas e pela profunda disparidade entre os diferentes grupos sociais.

Foi neste contexto que o projeto de Vasconcelos se tornou viável e interessante politicamente. Sua concepção particular da educação, entretanto, estava longe de ser

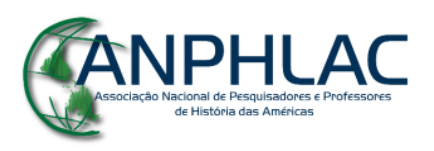

Revista Eletrônica da ANPHLAC, ISSN 1679-1061, №. 23, p. 82-118, Jul./Dez., 2017.

http://revista.anphlac.org.br 
unívoca e vinha carregada de percepções estéticas e filosóficas que muitas vezes não dialogavam com o que se discutia no âmbito da pedagogia. Além disso, sua visão particular da história do México recorria constantemente a categorias de análise dualistas como "civilização" e "barbárie", "construção" e "destruição". Para representar esta dualidade, são recorrentes, no discurso vasconceliano, duas imagens: uma é a da luta entre a águia e a serpente - relacionada ao mito fundacional do país, a migração dos mexicas (ou astecas) de Aztlán para o vale do México, seguindo o voo de uma águia com uma serpente no bico. A outra é a da luta entre os deuses Quetzalcóatl e Huitzilopochtli, o primeiro, representante do conhecimento pacífico e eterno do qual resultaria o advento da civilização mexica, e o segundo, um sanguinário deus destruidor que teria corrompido a tradição indígena com sua violência e sua exigência de sacrifícios humanos.

Ainda que tal leitura desta tradição mitológica divirja radicalmente do conteúdo cosmológico associado a estas divindades pelos próprios mexicas (MOCTEZUMA, BORDIN, 2003), é interessante notar como Vasconcelos recupera elementos da tradição indígena para legitimar a autenticidade de sua proposta filosófica e educacional. Quetzalcóatl seria o deus responsável pela civilização. Seria, portanto, a divindade ligada por excelência à educação:

\begin{abstract}
No será completo ningún relato de la historia de la educación pública en nuestro continente hispánico si no se comienza mencionando a Quetzalcóatl, el personaje fabuloso de la tradición azteca, que llegó de lejos, cargado de ciencia y de virtud, y se puso a enseñar las artes y a reformar las costumbres. Fácilmente logró Quetzalcóatl multiplicar sus discípulos y desarrollar las industrias, a la vez que las prácticas más rudas se dulcificaban con el ejercicio de la sabiduría. Rápidos y asombrosos fueron los éxitos del educador porque ya desde entonces la raza era de ingenio vivo. [...] Y vino un período de claridad, una edad de oro de la cual procedía lo bueno que tuvieron los aztecas. Pero sucedió lo mismo que tantas veces ha ocurrido después, sucedió que la influencia de Huitzilopochtli, el dios sanguinario, vuelve a prevalecer y mantiene sobre aquel territorio una especie de maldición y de locura homicida. (VASCONCELOS, 2009f, p. 102)
\end{abstract}

Se a educação, para Vasconcelos, seria o único caminho que poderia transformar a destruição em construção, construir era conceito muito próximo ao de servir: servir ao próximo em uma ação abnegada e despretensiosa - e os principais atores deste serviço seriam os professores. No mesmo discurso de posse em que Vasconcelos pediu que a

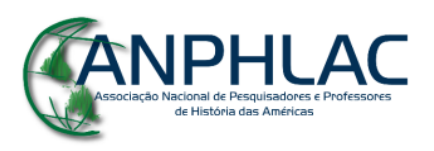

Revista Eletrônica da ANPHLAC, ISSN 1679-1061, №. 23, p. 82-118, Jul./Dez., 2017.

http://revista.anphlac.org.br 
Universidade trabalhasse pelo povo, ele propôs uma postura que aproximaria o professor e o intelectual ao conquistador espanhol e seus missionários católicos, com seu "ardor apostólico" e seu "fervor evangélico" (a epígrafe deste artigo reafirma isso de maneira muito clara). Não se trata de conceber a educação como missão apenas no sentido de que ela seria uma incumbência, um dever, ou mesmo o destino reservado àqueles que deveriam levar o México a um novo patamar de civilização. Vasconcelos propõe que a educação deve ser entendida no plano de uma missão religiosa, apostólica, tendo como grande modelo o evangelismo do período colonial.

Evidentemente, ao se conceber o processo educativo desta forma, cristaliza-se determinada imagem a respeito do educador e do educando, particularmente quando este educando é, em sua maior parte, a população pobre e os povos indígenas. Ainda no discurso acima referido, Vasconcelos afirmou: “Al decir educación me refiero a una enseñanza directa de parte de los que saben algo, a favor de los que nada saben”. Entre esse "algo" a ser ensinado, teríamos "hábitos de trabajo, hábitos de aseo, veneración por la virtud, gusto por la belleza y esperanza en sus propias almas". Entre os que nada sabem, "el indio [...], el humilde" (VASCONCELOS, 2009c, p. 142-143). O "problema indígena" estava profundamente atrelado à urgência de se construir a nação mexicana e o fato de a educação (particularmente a educação indígena) ser vista como uma missão análoga às missões religiosas do período colonial, frente àqueles que nada sabem, pode nos indicar alguns caminhos e limites do projeto educacional de Vasconcelos.

\section{A Campanha contra o Analfabetismo}

A primeira medida de grande alcance que Vasconcelos empreendeu a frente da reitoria da Universidade Nacional foi a Campanha contra o Analfabetismo. Ainda que propor um esforço de alfabetização nacional escapasse, em muito, à competência de seu cargo, esta ação já apresentava um dos recursos de que Vasconcelos se serviria largamente à frente da Secretaria de Educação Pública (SEP), mais à frente: o apelo, através de chamados públicos, à ação desinteressada individual, de caráter missionário e altruísta, como alternativa à falta de recursos orçamentários.

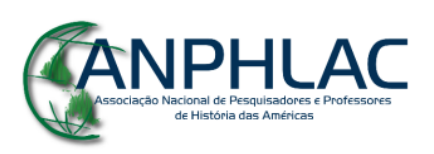

Revista Eletrônica da ANPHLAC, ISSN 1679-1061, №. 23, p. 82-118, Jul./Dez., 2017.

http://revista.anphlac.org.br 
Ao longo de 1920, Vasconcelos divulgou cinco circulares dando conta do programa da Campanha. Fazendo isso, foi muito bem acolhido pela imprensa e por boa parte da classe educadora, que denunciava havia muito tempo a altíssima taxa de analfabetismo da população, inclusive no Congresso Nacional de Professores de Ensino Básico realizado no mesmo ano de 1920 (FELL, 1989, p. 24).

Além do recurso ao chamado público, muitas das características da Campanha se assemelhavam ao projeto que Vasconcelos levaria a cabo nos anos subsequentes. Nas circulares que lançou, o reitor procurava afirmar que, mais do que alfabetizar, cabia ensinar à população fundamentos de asseio e higiene, evidenciando uma preocupação que ia além do ensino dos rudimentos do castelhano e almejava uma regeneração de fundo moral da população. Tal regeneração deveria ser atingida com uma educação cívica voltada para o ensino das virtudes da civilização - mas, para tanto, deveria começar com os hábitos mais básicos.

Como protagonistas do encargo alfabetizador, foram criados corpos de "professores honorários" - homens e mulheres (o chamado às mulheres foi uma grande ênfase de Vasconcelos) que deveriam, para ser admitidos como tais, ter no mínimo três anos de educação primária e ser plenamente alfabetizados. Seu trabalho seria voluntário e gratuito e suas obrigações consistiriam em ministrar aulas de alfabetização, ao menos uma vez por semana, a duas ou mais pessoas, fosse em sua casa ou em qualquer outro espaço, de dia ou, sobretudo, à noite. A partir deste esforço, a cada cem alunos alfabetizados o professor honorário receberia um diploma, que lhe garantiria uma preferência na busca de um emprego entre os cargos ministeriais.

A execução desta Campanha, entretanto, teve uma série de graves entraves. Dos alunos que participaram dela, muitos assistiam às aulas com pouca regularidade, e a desconfiança para com os professores era muito grande. Além disso, faltavam materiais para as aulas, como cartilhas, cadernos e quadros negros. O desequilíbrio da iniciativa no campo e nas cidades era imenso: no campo, ela era ainda mais árdua, aliando distâncias geográficas, falta de infraestrutura, a existência de populações indígenas que não falavam o espanhol e a oposição de grandes fazendeiros que a consideravam uma ameaça.

Além do desequilíbrio entre o campo e as cidades, subsistia uma imensa discrepância entre a ação alfabetizadora no Distrito Federal e nos demais estados

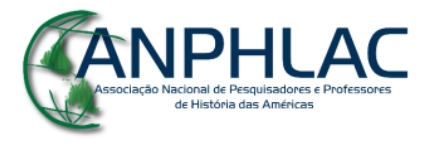

Revista Eletrônica da ANPHLAC, ISSN 1679-1061, №. 23, p. 82-118, Jul./Dez., 2017.

http://revista.anphlac.org.br 
mexicanos. Historicamente, a jurisdição de um ministério voltado para a educação pública dificilmente transbordara os limites do Distrito Federal, sendo esta uma das grandes limitações do trabalho de Justo Sierra e dos demais secretários que assumiram o seu cargo até o fechamento da Secretaria de Instrução Pública e Belas Artes, em 1917. Durante a atuação de Vasconcelos, esta discrepância continuou: as ações geralmente eram testadas no Distrito Federal, onde teriam maior possibilidade de serem levadas a cabo, e depois se tentava expandi-las para os outros estados.

No caso da Campanha conta o Analfabetismo, Vasconcelos solicitou, em nota de 15 de março de 1921, que os governadores de todos os estados nomeassem um inspetor para supervisionar a Campanha e compilar informações estatísticas a seu respeito. As autoridades de alguns estados acederam, mas mesmo assim o potencial de ação era muito pequeno, de modo que se pensou em colocar novamente em prática a ideia da "escola rudimentar", que incluía a atuação no campo e junto às comunidades indígenas (FELL, 1989, p. 39).

Claude Fell nos recorda que a escola rudimentar não era uma novidade no México: em 1911, um decreto dera conta da sua criação. Nesta época, uma assembleia de professores, reunida com o fim de garantir a aplicação do princípio da instrução primária obrigatória, definiu que tais escolas ficariam (duas ou três de cada vez) sob a responsabilidade de um maestro ambulante (FELL, 1989, p. 215-216). Em 1921, o reavivamento destas instituições rudimentares procurava organizar a ação dos professores honorários em escolas que funcionassem durante o dia, para as crianças, e durante a noite, para os adultos (FELL, 1989, p. 39). Princípios de higiene, civismo, rudimentos da matemática ficariam ao encargo destes professores, além da própria alfabetização. Na falta de edifícios para abrigar todos estes esforços, decidiu-se pela construção de 500 tendas de campanha a serem colocadas especificamente nas praças e jardins de bairros populosos do Distrito Federal (MORALES, 1983, p. 313).

Ao longo do ano de 1921, a Secretaria de Educação Pública foi definitivamente criada e Vasconcelos deixou o cargo de reitor para assumir o de secretário da SEP. A Campanha passou, desta forma, a ser controlada diretamente pela Secretaria, por meio de seu Departamento da Campanha contra o Analfabetismo (um departamento que se propunha de caráter temporário). Neste contexto, Abraham Arellano (que assumiu a direção da Campanha de 1921 a 1922) enviou, em 08 e agosto de 1921, um informe

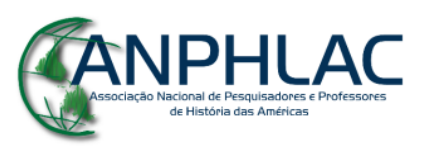

Revista Eletrônica da ANPHLAC, ISSN 1679-1061, №. 23, p. 82-118, Jul./Dez., 2017.

http://revista.anphlac.org.br 
detalhando o pequeno alcance que o esforço alfabetizador tinha tido até o momento, e o fracasso das escolas rudimentares.

Para ele, o centro da Campanha contra o Analfabetismo deveria ser os maestros ambulantes (que teriam seu estatuto definido mais à frente), trabalhando em harmonia com os professores honorários. A Campanha ganharia o reforço de instituições criadas no âmbito da SEP, como as "missões culturais" (cuja atuação ultrapassava o esforço alfabetizador) e os "centros de alfabetização" (de que tratarei abaixo). Ao mesmo tempo, o apelo voluntarista aos professores honorários continuava, inclusive com a criação do "Exército Infantil", do qual participariam automaticamente todas as crianças do quarto, quinto e sexto anos do ensino primário (FELL, 1989, p. 40-42).

Os centros de alfabetização, centros culturais, ou, oficialmente, "Centros de Educação e de Cultura Social", iniciaram-se, como seria de se esperar, no Distrito Federal, contando com a participação de um corpo de professores itinerantes que passaria quatro meses em cada centro. Em 1922, foram abertos sete centros no Distrito Federal e outro em Puebla, sendo fundado mais um centro no Distrito Federal no início do ano seguinte. A ideia era que se pudesse, através deles, não só ampliar o acesso à educação formal para alunos em situação de carência, como também transformar estes espaços em locais de referência das comunidades em que se encontravam. Nesse sentido, eram também centros de saúde pública e assistência social (FELL, 1989, p. 42).

Também foram fundados "Centros Noturnos de Desanalfabetização", com professores pagos. Apenas no ano de 1923, abriram-se 65 centros na cidade do México (geralmente compartilhando o espaço com escolas públicas diurnas). No Distrito Federal, o trabalho dos centros era controlado por três inspetores, mas, nos estados, eram os "maestros misioneros" (cuja atuação será detalhada mais à frente) os seus responsáveis. Nestes casos, os professores das escolas rurais empregavam uma hora do seu dia para ensinar crianças e adultos analfabetos (FELL, 1989, p. 42-43).

Entretanto, em que pese tudo isso, os resultados continuaram modestos. Eulalia Guzmán, sucessora de Arellano na direção da Campanha, organizou, em 1923, um censo relativo ao esforço alfabetizador no Distrito Federal e nos demais estados. Estes dados contestam outros, mais otimistas, como os do presidente Álvaro Obregón - que afirmou, em informe presidencial, que, até setembro de 1922, 52 mil pessoas haviam sido alfabetizadas no México. Contestam também os números do próprio José

\section{GANPHLAC}

Revista Eletrônica da ANPHLAC, ISSN 1679-1061, №. 23, p. 82-118, Jul./Dez., 2017.

http://revista.anphlac.org.br 
Vasconcelos, que, em Indología, declarou que a atuação da campanha teria levado a uma diminuição anual de 50 mil analfabetos (FELL, 1989, p. 45-46). A tabela abaixo compila alguns dados estatísticos apresentados por Eulalia Guzmán em outubro de 1923:

Tabela 1: Resultados da Campanha no ano de $1923^{3}$

\begin{tabular}{l|c|} 
Instituições & Número total de alunos completamente alfabetizados \\
\hline Centros & 1.477 \\
\hline Centros diurnos & 8.617 \\
\hline Professores honorários em geral & 14.156 \\
\hline Professores honorários estudantes & 4.755 \\
\hline Exército infantil & 8.979 \\
\hline TOTAL & 37.984 \\
\hline
\end{tabular}

Os dados compilados por Guzmán apresentam algumas informações interessantes. Uma das mais evidentes é a de que, ainda que centros culturais diurnos e noturnos tenham sido criados, o impacto maior da Campanha ainda residia nos professores honorários e, portanto, na ação voluntária. O número total de 37.984 alfabetizados em 1923 também nos permite chegar a conclusões importantes. Como Fell destaca, o ano de 1923 foi particularmente frutífero para a Campanha, que seria reduzida em suas proporções a partir de 1924, quando o Departamento da Campanha contra o Analfabetismo foi extinto como um departamento autônomo da SEP, e quando uma série de conjunturas (que serão discutidas no final deste artigo) levou a uma substancial diminuição da verba destinada à Secretaria. Desta forma, Fell estima, pelos dados de 1923, que durante os quatro anos que durou a Campanha, deve ter havido uma média de não mais do que 80 ou 100 mil alfabetizados por meio deste esforço.

Tais números não são nada irrelevantes, se levarmos em consideração que este era o primeiro grande trabalho de alfabetização coletiva que se promovia no México, sobre o qual recaiu o mérito da invenção e o ônus dos erros e projeções equivocadas. De todo modo, se os compararmos à população total do México no período e, mais especificamente, ao percentual calculado de analfabetos, veremos que o alcance da Campanha foi muito modesto. O censo oficial realizado em 1921 apontava para uma população total de 14.334.780 de habitantes. Estimava-se que, em um universo de

\footnotetext{
${ }^{3}$ Esta tabela é uma adaptação da que Claude Fell organiza em FELL, 1989, p. 47.

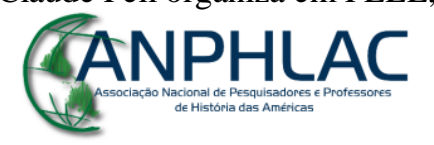

Revista Eletrônica da ANPHLAC, ISSN 1679-1061, №. 23, p. 82-118, Jul./Dez., 2017.

http://revista.anphlac.org.br
} 
10.621.740 maiores de dez anos, 6.879.348 não sabiam ler nem escrever, ou seja, $64,76 \%$ do total analisado.

Entretanto, deve-se ressaltar que este senso foi realizado em condições excepcionais, sendo o primeiro ocorrido depois do período da guerra civil (1910-1920). A Direção Geral de Estatística possuía um orçamento muito limitado para realizá-lo, ao que se somava a resistência de alguns estados em colaborar e a falta de pessoal preparado (INSTITUTO NACIONAL, p. 19-22, 102-106). Claude Fell trabalha sempre com a cifra de $80 \%$ de analfabetos no país - número que podia chegar a $91 \% \mathrm{em}$ Chiapas ou 88\% em Oaxaca (FELL, 1989, p. 661). Entretanto, apesar da consistência e da seriedade de seu clássico trabalho José Vasconcelos: los años del águila (19201925), não está clara a fonte de onde o autor consegue estes números; de todo modo, eles parecem bem mais realistas do que os registrados no censo.

Se considerarmos a mesma população de 1921 para o final de 1924 e levarmos em consideração a conjectura de Fell para o número total de alfabetizados pela Campanha em seus quatro anos de duração, e aceitando ainda os métodos utilizados pelo censo de 1921 para definir o número de analfabetos, podemos inferir que apenas por volta de 1,4\% do número total de analfabetos em 1921 foi alfabetizado pela Campanha até o final de 1924. Considerando os números apresentados por Fell quanto ao iletramento, o percentual cai para $0,9 \%$ de analfabetos alfabetizados neste período. Estes números nos trazem uma dimensão mais concreta do alcance da Campanha contra o Analfabetismo e contrastam fortemente com a memória que se construiu a seu respeito como a de uma grande cruzada que mobilizou massivamente o México em prol do letramento da população pobre.

\section{Educação e estética}

Uma das tendências gerais da atuação de Vasconcelos, que já aparecia na Campanha contra o Analfabetismo, diz respeito à busca de se promover uma verdadeira "educação", mais do que uma mera "instrução" (concepção que se manifesta no nome da Secretaria criada em 1921 - até 1917, ela era concebida como "de Instrução Pública"). O ensino não deveria se contentar com o meramente rudimentar, a

\section{GANPHLAC}

Revista Eletrônica da ANPHLAC, ISSN 1679-1061, №. 23, p. 82-118, Jul./Dez., 2017.

http://revista.anphlac.org.br 
alfabetização pura e simples, ou com o ensino de teorizações que estivessem desvinculadas da realidade dos alunos. Deveria, isso sim, atender às suas necessidades imediatas, inserindo-os no mundo do trabalho e fazendo com que seu nível de vida melhorasse.

De todo modo, a finalidade última da educação, para Vasconcelos, não poderia se concentrar, jamais, em seu aspecto puramente utilitário. Havia uma preocupação que ia além da dimensão prática, transcendendo o material, uma dimensão que unia o estético ao espiritual (o primeiro sendo o caminho para o segundo). Era necessária uma educação técnica para sobreviver (e para combater a ociosidade contrária ao progresso e à moral) e arte para elevar o espírito. Esta dupla função da educação acabava por unir trabalhadores e intelectuais: "aprendiendo el intelectual, la santidad que se deriva del trabajo, y conociendo el trabajador, la luz que emana de las ideas" (VASCONCELOS, 2009a, p. 156).

A proposta de elevação espiritual através da luz das ideias e do "gozo estético" se relaciona com a particular inspiração religiosa de Vasconcelos, que conseguia unir um catolicismo missionário a ideias esotéricas e leituras sui generis de pensadores clássicos. De fato, Vasconcelos defendia o laicismo escolar, mas se mostrava contrário a um ateísmo radical que se aproximava, em sua opinião, do completo niilismo. Foi isso que escreveu em uma carta-prefácio a um estudo de Federico González Garza em 1918:

\footnotetext{
necesitamos, antes que ninguna cosa, educación moral... Necesitamos una educación que nos enseñe, no sólo a ser técnicos de la moral, sino a practicarla un poco. Yo he dicho muchas veces en la conversación que padecemos un ateísmo radical: el ateísmo religioso, el político, el ético, el estético; en general, el nihilismo de todos los ideales. La baja doctrina del éxito es la norma de todos nuestros juicios; por eso ha sido tan merecido el azote divino que todavía flagela a nuestra patria. (FELL, 1989, p. 118, nota de rodapé n. 100)
}

A ênfase na educação moral se relaciona com a posição de Vasconcelos ante as doutrinas pedagógicas. O espiritualismo cultivado pelo Ateneo de la Juventud, de que fizera parte, e a franca oposição às teorias racionalistas e materialistas dos positivistas, deixaram um lastro de desconfiança em relação ao cientificismo particularmente acentuado em Vasconcelos. Ao invés do cientista amparado pela teoria, preferia o

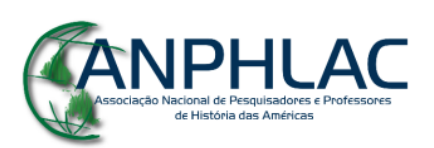

Revista Eletrônica da ANPHLAC, ISSN 1679-1061, №. 23, p. 82-118, Jul./Dez., 2017.

http://revista.anphlac.org.br 
missionário amparado por sua vontade firme e abnegada, pelo cultivo de sua moral e pela sua inspiração divina.

Tais elementos são amparados na teoria estética que desenvolveu na década de 1910 e que se manifestou particularmente em suas obras Pitágoras: una teoría del ritmo e El monismo estético: ensayos. Sua ideia era a de que a percepção do mundo era possível através da vertente intelectual e científica e através de outra vertente intuitiva, de base estética. A ciência e as formas tradicionais de educação valorizavam a primeira vertente, mas, para Vasconcelos, ela só teria sentido se fosse conciliada com a segunda. Acreditar que o mundo só poderia ser conhecido pela razão seria aceitar o discurso materialista anglo-saxão. A tradição latina mostrava, por outro lado, que havia um espírito acessível por meio da compreensão estética.

O caminho para este espírito seria a intuição, cuja formulação seguia a proposição de Bergson, tão cara aos ateneístas. Vasconcelos conciliava com a ideia de intuição a teoria pitagórica do ritmo, um ritmo inerente a todas as coisas do mundo, que as dotaria de movimento. A percepção deste ritmo seria de base fundamentalmente estética: através do ideal de beleza, inspirado pelo espírito, seria possível intuir uma ordem regular e infinita a todas as coisas, de fundo místico. Por isso, Vasconcelos evocava também a ideia plotiniana de "monismo": a concepção de uma unidade primeira do ser, anterior à diferenciação entre ser e matéria.

Devemos ter em mente que, dentro desta formulação, alcançar a percepção desta ordem só se tornaria viável através de uma ascesis, de um isolamento, por parte da alma, dos desejos que vêm do corpo. A ideia desta ascesis também possui inspiração em Plotino, que considerava que, mais do que adquirir uma cultura material, caberia cuidar da vida espiritual e purificar a alma. Juntamente ao ascetismo, o movimento de intuição de uma ordem universal deveria vir através do gozo proporcionado pela arte e pela apreciação estética do mundo. A contemplação da natureza deveria ter protagonismo neste processo, e seus temas deveriam prevalecer na arte. $\mathrm{O}$ artista deveria ser livre para retratar, em suas obras, o resultado da sua apreciação do mundo, sem se submeter a nenhuma outra lógica (idealismo, militância, ou mesmo nacionalismo) que não a sensibilidade estética.

Tais aspectos balizaram a concepção de arte de Vasconcelos, ainda que os artistas financiados pela SEP, na maior parte das vezes, não compartilhassem de suas

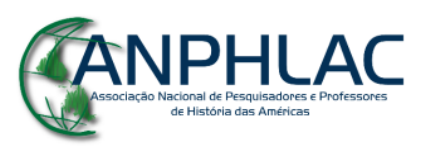

Revista Eletrônica da ANPHLAC, ISSN 1679-1061, №. 23, p. 82-118, Jul./Dez., 2017.

http://revista.anphlac.org.br 
concepções. Os muralistas, por exemplo, cujo grande apogeu se deu em função do patrocínio da Secretaria, produziram frequentemente obras eivadas de uma militância social e de uma identificação com a vida material dos homens, muito mais do que com o gozo estético que emanaria da natureza. ${ }^{4}$

\section{Criação e funcionamento da SEP}

Ao iniciar sua Campanha contra o Analfabetismo, Vasconcelos mostrava que não demoraria a iniciar seu trabalho de "regeneração nacional". Entretanto, para que este trabalho pudesse ser efetivo, fazia-se fundamental a reconstrução de uma secretaria federal de educação pública, cuja atuação pudesse realmente se estender para além do Distrito Federal, atingindo todos os estados da federação e, sobretudo, as massas indígenas e camponesas. Os trâmites legais para a execução desta proposta incluíam a reformulação de artigos da Constituição que permitiria à Câmara de Deputados legislar sobre questões relativas à educação pública nacional. Em 09 de fevereiro de 1921, as mudanças foram aprovadas.

Entretanto, conforme o próprio Vasconcelos mais tarde escreveria, no terceiro tomo de sua autobiografia, El desastre: "Aparte de la reforma constitucional, urgía presentar al Congreso la Ley que serviría de norma al nuevo Ministerio. Para formularla era menester el visto bueno del Consejo Universitario". Entretanto, reiterando a concepção que tinha da necessidade de uma ascesis para que a mente pudesse intuir a ordem universal e ser inspirada por ela (e vendo a si mesmo sempre como figura chave nesse processo), Vasconcelos declarou:

\footnotetext{
${ }^{4}$ Esse elemento é interessante porque demonstra que houve certa liberdade para artistas e demais profissionais envolvidos com o projeto educacional de Vasconcelos. Constantes são as críticas de que seu caráter centralista teria constituído uma postura dirigista, extremamente controladora. Entretanto, contra essa ideia de que haveria um "dirigismo" (marcante no trabalho de Claude Fell, por exemplo), Romilda Costa Motta argumenta que este conceito traz "uma carga de autoritarismo que, se formos observar a fundo, não [corresponde] aos resultados alcançados pelo projeto cultural da SEP. [...] A análise das fontes nos permite afirmar que, de fato, não houve imposição aos artistas e que estes tiveram, sim, liberdade na escolha das temáticas e estilos. [...] Concordamos que a administração de Vasconcelos estava distante do modelo que poderíamos considerar democrático. No entanto, preferimos afirmar que ela foi, indubitavelmente, centralizadora e não exatamente dirigista ou arbitrária, visto que entendemos que houve margem para manifestações contrárias ao estabelecido e desejado por Vasconcelos" (MOTTA, 2010, p. 124-125).
}

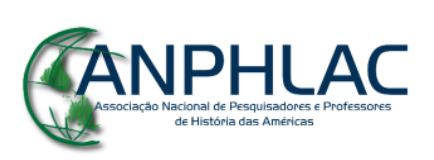

Revista Eletrônica da ANPHLAC, ISSN 1679-1061, №. 23, p. 82-118, Jul./Dez., 2017.

http://revista.anphlac.org.br 
Nunca he tenido fe en la acción de asambleas y cuerpos colegiados, y más bien me impacienta tratar con ellos. Sirven [...] para dar alguna sugestión; pero, en esencia, para ratificar, legalizar la obra de un cerebro que a la hora de crear necesita sentirse solo, saberse responsable en lo individual. (VASCONCELOS, 1982a, p. 18-19)

Em 25 de julho, seria a vez de o presidente Álvaro Obregón publicar o decreto em que criava oficialmente a Secretaria de Educação Pública e Belas Artes (SEP), decreto que foi aprovado por unanimidade pelos deputados em 05 de agosto.

A 10 de outubro, Vasconcelos foi nomeado oficialmente secretário de educação pública, e o orçamento destinado à Secretaria foi estipulado em 15 milhões de pesos. Tal orçamento, ainda que fosse o maior já destinado à educação pública no país, era muito inferior àquele necessário para abarcar a ambiciosa proposta de Vasconcelos, o que abriu caminho para um extenso debate, a partir de dezembro de 1921, em que o discurso da regeneração do país foi mobilizado junto à opinião pública e aos deputados. Finalmente, aprovou-se como orçamento a incrível quantia de 51 milhões de pesos apenas inferior àquele destinado à Secretaria de Guerra e Marinha. Entretanto, de acordo com um informe presidencial de 1923, apenas 30.688 .465 pesos de fato foram destinados à SEP no ano de 1922 (FELL, 1989, p. 66-69).

Ainda em meio às discussões relativas ao orçamento que seria destinado à SEP, como nos lembra Claude Fell, vários deputados destacaram a necessidade de se incentivar a educação rural e indígena nos estados. Em 04 de janeiro de 1922, os deputados do Partido Liberal Constitucionalista, encabeçados por José Siurob e Juan B. Salazar, solicitaram a criação de um Departamento de Educação e Cultura Indígena como iniciativa fundamental à "regeneração" dos milhões de índios mexicanos. Vasconcelos era bastante reativo, como veremos, à ideia de criar um departamento específico para esta atividade, acreditando que o modelo de uma escola específica para indígenas se aproximaria do sistema de reservas indígenas aplicado nos Estados Unidos. Pelo contrário, se o objetivo era integrar o indígena no México, seria fundamental que ele estivesse inserido nos mesmos planos de educação e nas mesmas instituições reservadas à população mexicana em geral, sem qualquer espécie de segregação. Ainda em El desastre, Vasconcelos recordou um momento em que antropólogos estadunidenses lhe ofereceram seus serviços, após realizarem pesquisas na Bolívia. Sua

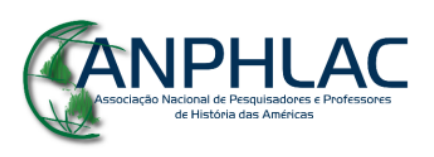

Revista Eletrônica da ANPHLAC, ISSN 1679-1061, №. 23, p. 82-118, Jul./Dez., 2017.

http://revista.anphlac.org.br 
resposta foi que, no México, já se pesquisava o tema da educação indígena havia quatro séculos, a começar pelos educadores espanhóis.

Por otra parte, les dije: "Si hacemos reservación, como en los Estados Unidos, ¿quién va a distinguir al que es indio del que no lo es? Todos nosotros tendríamos que meternos a la reservación. Por fortuna, aquí dejamos de ser indios desde que nos bautizan. El bautismo dio a nuestros ancestros categoría de gentes de razón, y basta". (VASCONCELOS, 1982a, p. 20)

De todo modo, a criação do Departamento de Educação e Cultura Indígena foi aprovada por unanimidade no Congresso, medida aceita por Vasconcelos, que fez questão de frisar seu caráter temporário, o mesmo que teria o Departamento da Campanha contra o Analfabetismo. A estrutura elaborada por Vasconcelos deveria ser tripartite: o Departamento Escolar propriamente dito seria acompanhado pelo Departamento de Bibliotecas e Arquivos e pelo Departamento de Belas Artes, complementados, então, pelos dois departamentos provisionais, que não deveriam senão garantir que a população mexicana em sua totalidade estivesse em condição de gozar das instituições regulares de educação e cultura. O esquema de funcionamento da SEP, portanto, era o seguinte:

\section{Estrutura geral da SEP}

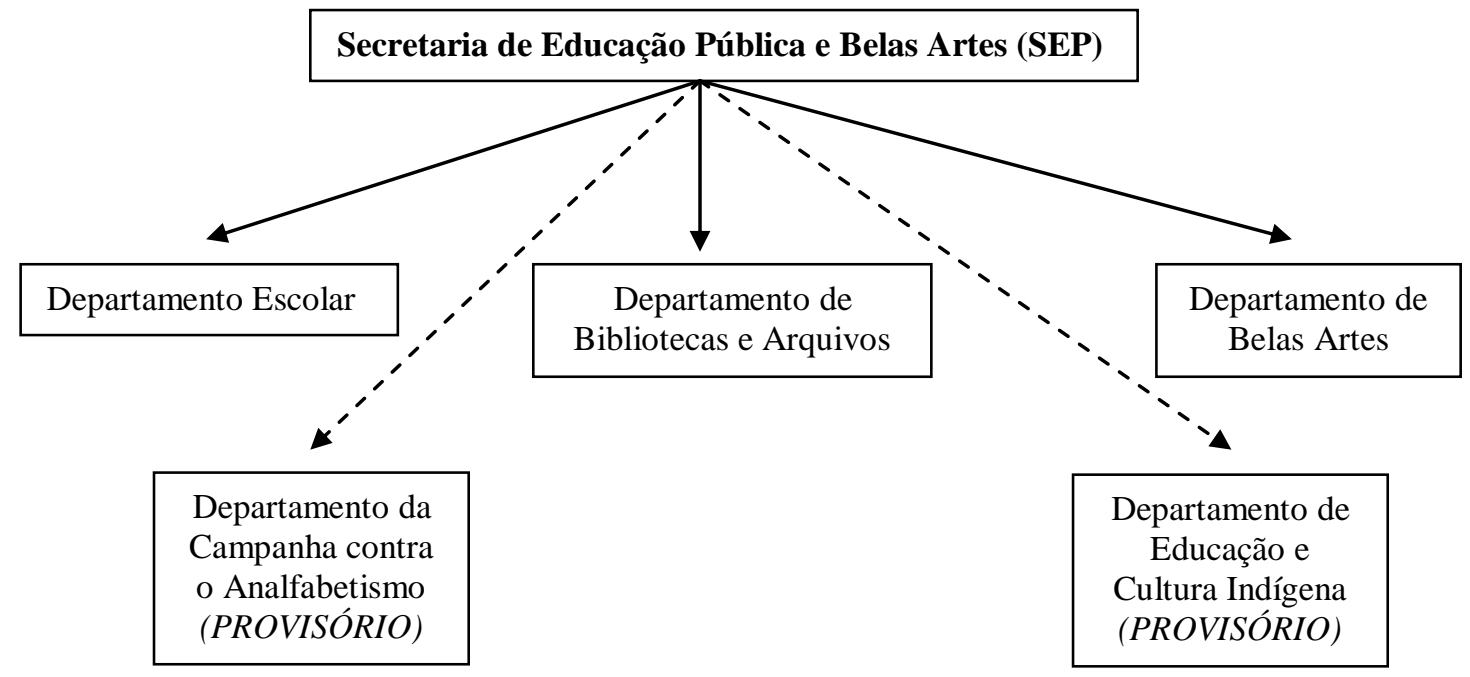

Através da atuação do Departamento de Bibliotecas e Arquivos, segundo dados presentes nos Boletines de la SEP, até o final de 1923, 1.911 novas bibliotecas haviam

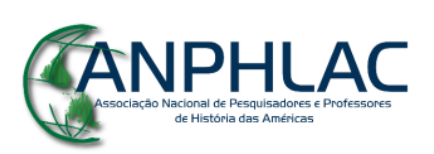

Revista Eletrônica da ANPHLAC, ISSN 1679-1061, №. 23, p. 82-118, Jul./Dez., 2017.

http://revista.anphlac.org.br 
sido criadas e 179.909 livros distribuídos (MORALES, 1983, p. 348). Nos acervos das bibliotecas, o objetivo central era que os livros não se restringissem às coleções datadas da época do Porfiriato: deveriam contemplar tanto a vida prática da população, com materiais técnicos e profissionais, quanto a sua formação moral e espiritual, em nome da qual se publicavam livros que tivessem caráter e inspiração "universais".

Nesse sentido, criou-se um Departamento Editorial na SEP. Não se tratava de um departamento autônomo, como os três departamentos principais e os dois provisionais, mas de uma instituição subordinada ao Departamento de Bibliotecas e Arquivos. A partir dele, várias coleções foram impressas, distribuídas em bibliotecas, carregadas por "maestros missioneiros" que conduziam "bibliotecas ambulantes", e, de forma massiva, vendidas a preços módicos para "ilustrar" a população. Dentre as coleções, destacam-se Las lecturas clásicas para niños, Lecturas clásicas para mujeres (preparada por Gabriela Mistral) e, sobretudo, os famosos Clásicos: livros escolhidos por Vasconcelos, com tiragens de 20 a 25 mil exemplares, que contemplaram 17 títulos de diferentes autores - de A Ilíada e A Odisseia, passando por Platão, Plotino, Ésquilo e Eurípedes, chegando até Dante, Romain Rolland, Tolstói e Goethe. Evidentemente, houve muitas críticas aos enormes gastos havidos com a impressão e distribuição destes clássicos em um país predominantemente analfabeto. Além disso, reprovou-se muito a improbabilidade de que fosse possível atrair naturalmente a atenção da população não escolarizada a este tipo de leitura.

O Departamento de Belas Artes contava com três divisões que foram criadas para levar à população a política estética da Secretaria: a Direção de Cultura Estética, a Direção de Cultura Física e a Direção de Desenho e Trabalhos Manuais. A partir deste momento, comenta Fell citando as palavras de Vasconcelos,

el canto, el dibujo y la gimnasia no sería ya responsabilidad de los maestros, sino de los 'centenares de buenos músicos y de hábiles artistas cuyos servicios nadie ocupaba una vez que salían de nuestro Conservatorio o de la Escuela de Bellas Artes'. (FELL, 1989, p. 395)

Além do ensino de educação artística, musical e física nas escolas (levando a cabo a máxima de que era necessário controlar o corpo e mantê-lo são e, ao mesmo tempo, elevar o espírito através da fruição da arte), houve a manutenção de museus e

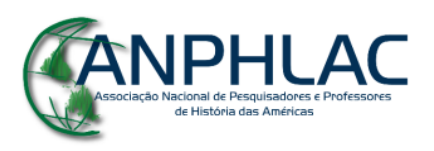

Revista Eletrônica da ANPHLAC, ISSN 1679-1061, №. 23, p. 82-118, Jul./Dez., 2017.

http://revista.anphlac.org.br 
escolas de arte e o patrocínio a diversas formas de artes plásticas (notadamente a pintura mural). Além disso, muitos investimentos foram feitos em concertos públicos, espetáculos de música e danças folclóricas. Soma-se a isso a construção de ginásios e a monumental obra do Estádio Nacional, anunciada em inícios de 1922 e inaugurada às pressas em maio de 1924, pouco antes de Vasconcelos deixar a SEP. Sua estrutura comportava uma capacidade para abrigar 60 mil expectadores, tanto para os jogos quanto para apresentações teatrais e festividades públicas ao ar livre. Trata-se de uma obra monumental que simbolizava, como nenhuma outra, o papel da fruição da arte e da estética dentro da concepção de educação levada a cabo por Vasconcelos.

\section{A educação indígena e rural}

O reconhecimento da importância da educação voltada para os grupos indígenas não era uma novidade na tradição educacional mexicana. Se voltarmos a Justo Sierra, veremos que, em sua obsessão pela formação de uma "alma nacional" no México, o maior obstáculo a ser superado seria a "degeneração" do indígena (SANTOS JUNIOR, 2013). O caminho para a modernização do México seria, portanto, “desindianizá-lo" fosse através da mestiçagem, concebida como medida de embranquecimento biológico, fosse através de medidas educacionais que pudessem ilustrar os índios, muitas vezes começando por ensinar-lhes o castelhano que não falavam, e, dessa forma, afastando-os da barbárie. Este era um dos fatores que tornavam a federalização da educação um assunto tão importante, desde Sierra: sem um sistema nacional de educação unificado, como "civilizar" os indígenas das partes mais recônditas do México?

Ao longo da década de 1910, a discussão se intensificou, envolvendo um espectro imenso de opiniões divergentes. Gregorio Torres Quintero - que chegara a dirigir o serviço de Instrução Rudimentar na década de 1910 - tinha a proposta de que o mais importante seria fazer com que os indígenas abandonassem suas línguas vernáculas para adotarem o espanhol, rompendo, assim, com seu isolamento econômico e cívico. Abraham Castellanos, por seu turno, defendia que o simples ensino da língua (ainda que fundamental) seria muito pouco para garantir a unidade nacional: a tradição mexicana seria herdeira da tradição pré-hispânica, não da latina, de modo que o

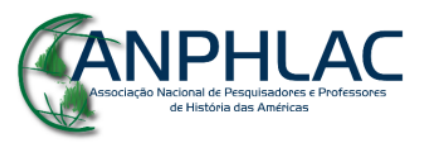

Revista Eletrônica da ANPHLAC, ISSN 1679-1061, №. 23, p. 82-118, Jul./Dez., 2017.

http://revista.anphlac.org.br 
espanhol deveria ser adotado, sim, como meio exclusivo de comunicação, mas veiculando elementos da própria tradição indígena.

Esta última postura era atacada por Vasconcelos, que considerava que o "antiespanholismo" tinha como consequência atirar o México ao imperialismo estadunidense (FELL, 1989, p. 204-206). A autonomia mexicana deveria vir da emancipação da população indígena - mas uma emancipação que não era concebida nos termos da tradição indígena, e sim de um ideal de progresso universal ao qual todas as raças seriam propensas. Na conferência que pronunciou no Continental Memorial Hall de Washington em 1922, Vasconcelos se posicionou contra as doutrinas eugênicas (evocadas frequentemente pelos intelectuais porfiristas, geralmente chamados de científicos) que eram céticas quanto à possibilidade de "redenção" do índio. Citando o princípio cristão de que todos os homens são filhos de Deus, defendeu que todas as raças eram, ou poderiam chegar a ser, aptas ao progresso:

\begin{abstract}
Escritores y educadores del viejo tipo científico expresaron con frecuencia la opinión de que nuestro pueblo, particularmente el indio y la clase trabajadora, constituían una casta irredimible, supuesto que, siendo el hombre un producto de la herencia y el medio, el mexicano auténtico no tenía esperanza de redención, porque su ángulo facial no correspondía a tales o cuales normas propias del tipo escocés o noruego y además, las circunstancias ambientes en que se verificaba su desarrollo eran de la peor clase. [...] [Nosotros] nos hemos dicho, recordando el Evangelio, más que las largas contradicciones y obtusas afirmaciones de la pedantería científica, que todos los hombres son hijos de Dios y que todas las razas son o pueden llegar a ser aptas. Algunas sobresalen en determinadas aptitudes y otras se distinguen por aptitudes diversas; pero importa al progreso y mejoramiento del mundo que todas las razas y que todos los hombres sobrevivan y conquisten la libertad económica y política, a fin de que puedan lograr la expresión total de sus almas. (VASCONCELOS, 2009b, p. 194)
\end{abstract}

Entretanto, a forma de garantir que todas as raças alcançassem juntas o progresso não seria jamais mantê-las isoladas umas das outras. Já foi comentado que Vasconcelos, embora tenha aceitado o Departamento de Educação e Cultura Indígena da SEP, nunca foi um defensor de sua criação. De fato, sua posição em relação à educação da população indígena era a de que qualquer meio educacional que partisse do pressuposto da segregação no ambiente escolar não poderia servir para integrar o índio à sociedade mexicana - aproximando-se do sistema de "reservas indígenas", que

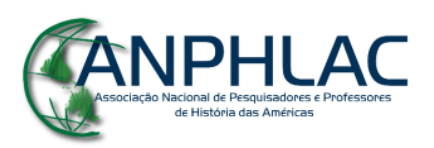

Revista Eletrônica da ANPHLAC, ISSN 1679-1061, №. 23, p. 82-118, Jul./Dez., 2017.

http://revista.anphlac.org.br 
circunscrevia as populações nativas a áreas restritas e isoladas nos Estados Unidos. Ainda na conferência de Washington, declarou:

\begin{abstract}
Recientemente se ha escrito mucho acerca de la mejor manera de educar a los indios de pura raza, siendo numerosos los partidarios de la creación de escuelas específicas de indios; pero siempre he sido enemigo de esta medida porque fatalmente conduce al sistema llamado de la reservación, que divide a la población en castas y colores de la piel, y nosotros deseamos educar al indio para asimilarlo totalmente a nuestra nacionalidad y no para hacerlo para un lado. En realidad creo que debe seguirse, para educar al indio, el método venerable de los grandes educadores españoles que, como Las Casas, Vasco de Quiroga y Motolinía, adaptaron al indio a la civilización europea, creando de esta suerte nuevos países y nuevas razas, en lugar de borrar a los naturales o de reducirlos al aislamiento. No concibo que exista diferencia alguna entre el indio ignorante y el campesino francés ignorante o el campesino inglés ignorante; tan pronto como unos y otros son educados, se convierten en auxiliares de la vida civilizada de sus países y contribuyen, cada uno en su medida, al mejoramiento del mundo. (VASCONCELOS, 2009b, p. 200-201)
\end{abstract}

Deve parecer claro que, quando Vasconcelos se referia ao indígena, estava se referindo a um tipo genérico e abstrato, que englobaria todas as populações ameríndias do México (e, virtualmente, de todo o continente americano). Vasconcelos defendia a possibilidade de integrá-lo à "vida civilizada" através da convivência nos mesmos espaços e nas mesmas instituições destinadas às populações não indígenas, mas fazia isso muito mais por uma convicção pautada em sua orientação filosófica de base universalista do que por um estudo sistemático de base pedagógica ou antropológica. $\mathrm{Na}$ verdade, Vasconcelos parecia muitas vezes desprezar estas áreas, por pretenderem "amesquinhar" a grandeza espiritual do homem dentro de rigores metodológicos.

Ao mesmo tempo, este índio aparecia como um sinônimo de camponês, o que reduzia a sua condição social e identitária à sua localização geográfica e sua atividade econômica. Tal atitude é evidente quando Vasconcelos afirma que não via diferenças entre os índios ignorantes e os camponeses franceses ou ingleses ignorantes. Afirmar que todos poderiam ser igualmente "educados" parece indicar que o caminho para esta "educação" é o mesmo, o que equivale a convertê-los em um tipo ideal (definido pela ignorância) que retoma o binarismo da oposição "civilização x barbárie”. É claro que tal postura não era exclusiva de Vasconcelos: compreender o indígena como sinônimo de camponês era uma atitude absolutamente frequente neste momento no México. Isso explica por que as expressões "educação indígena" e "educação rural” eram

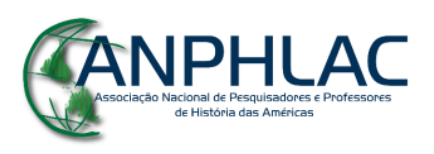

Revista Eletrônica da ANPHLAC, ISSN 1679-1061, №. 23, p. 82-118, Jul./Dez., 2017.

http://revista.anphlac.org.br 
praticamente equivalentes. Dentro da atuação do Departamento de Educação e Cultura Indígena, era comum tratar o índio como um camponês que necessitava ser alfabetizado em espanhol para, então, ser educado. Há muito tempo, esta postura vem sendo criticada, sendo um dos exemplos mais conhecidos a clássica obra México profundo: una civilización negada, de Guillermo Bonfil Batalla, que demonstra como a proposta de integração que tais projetos encampam pressupõe uma "desindianização" (BATALLA, 1987).

Entretanto, tal postura não era unívoca entre a intelectualidade mexicana. Afinal de contas, a década de 1920 foi também um momento de difusão da Antropologia Cultural de Franz Boas, que complexificou muito a compreensão dos grupos étnicos. Esta difusão se relaciona ao início do que Claude Fell chama de "movimento indigenista", surgido a partir de 1918-1920, e que começou a basear as suas formulações no trabalho de campo, fugindo das construções especulativas (ainda que, talvez - e o próprio Fell o reconhece -, falar de indigenismo nesta época seja um pouco precipitado).

Verifica-se, dentro deste círculo, uma passagem do modelo do ensaísta para o do antropólogo, do estabelecimento de leis a priori para a observação e o convívio com os grupos indígenas, com o objetivo de entendê-los. Um dos principais nomes deste processo de renovação foi o do antropólogo Manuel Gamio, que foi diretor, desde 1917, da Direção de Antropologia. Para que compreendamos até que ponto a "questão indígena" se reduzia à "questão agrária" no México, basta mencionar que esta Direção de Antropologia era um órgão subordinado à Secretaria de Agricultura (FELL, 1989, p. 208-209).

Gamio não divergia de Vasconcelos quanto à necessidade de que o índio fosse plenamente integrado à sociedade mexicana, buscando uma harmonia da população do país através da mistura, da homogeneização, da coesão nacional. Entretanto, compreendia que, para se ir "forjando pátria" (expressão que dá nome a seu mais famoso livro, de 1916) era fundamental compreender os grupos sociais mexicanos a partir das suas próprias realidades: só assim estes grupos poderiam se aproximar e se mesclar. Não seria possível integrar à sociedade mexicana um índio desconhecido.

Um grande exemplo nesse sentido foi o investimento feito pela Direção de Antropologia no conhecimento das línguas indígenas com o objetivo de

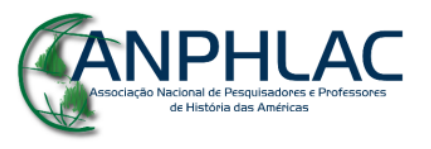

Revista Eletrônica da ANPHLAC, ISSN 1679-1061, №. 23, p. 82-118, Jul./Dez., 2017.

http://revista.anphlac.org.br 
permitir el estudio del idioma y la cultura, pero, sobre todo, para que puedan hacerse traducciones al catellano y hacer de éste la lengua dominante en los intercambios entre los diferentes grupos indígenas, y entre esos grupos y el resto del país. (FELL, 1989, p. 209)

Gamio não defendia o desaparecimento das línguas indígenas, mas propunha um bilinguismo: a língua espanhola seguia sendo vista como uma importante ferramenta de coesão nacional.

Percebemos que, para Gamio, a diversidade populacional era encarada ainda como um problema, acentuado pelas distorções históricas relacionadas à distribuição de terras e de recursos econômicos e de produção. Isso fazia com que o estudo etnográfico não fosse um fim em si mesmo, mas um meio para favorecer o desenvolvimento econômico, físico e intelectual das populações indígenas e assim preparar, nas palavras de Gamio, o "acercamiento racial, [la] fusión cultural, [la] unificación lingüística y [el] equilibrio económico" destes grupos (FELL, 1989, p. 210).

Diferentemente de Vasconcelos, que, entre outras coisas, rechaçava 0 bilinguismo como um meio de integração do indígena, Gamio defendia o exemplo estadunidense do U.S. Bureau of Indian Affair, alegando que ele proporcionava aos indígenas norte-americanos mecanismos para se desenvolverem e melhorarem sua situação econômica. O trabalho desenvolvido pela Direção no vale de Teotihuacán talvez seja o melhor exemplo do projeto de antropologia que desenvolviam: compreender a diversidade de um território delimitado, articulando as condições geográficas, os meios de produção, a situação social, as origens da pobreza; tudo isso aliado à busca de soluções para os problemas econômicos e educacionais da região.

Nesse sentido, além de iniciativas para promover o acesso à terra, a integração econômica e o desenvolvimento de setores manufatureiros e de turismo, criou-se um projeto de educação integral na região. Tal projeto possuía diversos pontos de convergência com o de Vasconcelos, incluindo o caráter centralista e, em certa medida, tutelar do processo educativo - ainda que a visão messiânica e apostólica do professor não estivesse presente. Houve especial atenção às noções de higiene, e as formas de arte tradicionais foram valorizadas. Além disso, o caráter cívico da educação era a tônica.

Nas palavras de Fell, citando Gamio, buscava-se explicar os conceitos

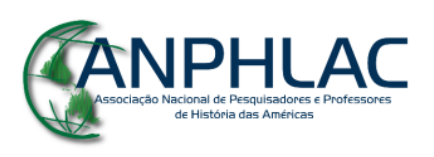

Revista Eletrônica da ANPHLAC, ISSN 1679-1061, №. 23, p. 82-118, Jul./Dez., 2017.

http://revista.anphlac.org.br 
de humanidad, de sociedad, de nacionalidad, de moral, de justicia, de cooperación, de altruismo y de ayuda mutua. Se explicaron 'los inconvenientes del fanatismo religioso, de las prácticas supersticiosas y mágicas, de la embriaguez y otros vicios'. (FELL, 1989, p. 212-213)

Tudo isso sem perder de vista os fundamentos da língua espanhola e da matemática, noções da história mexicana que pudessem promover a unidade nacional e o conhecimento mútuo, e elementos técnicos que promovessem a melhoria imediata das condições de vida destas populações.

Se, por um lado, a atuação da Direção de Antropologia parece ter um caráter menos "aculturante" do que a da SEP - patente na busca de compreensão das sociedades indígenas segundo seus próprios referenciais -, por outro lado, é evidente a associação entre a prática educativa e a incorporação, por parte dos indígenas, de elementos cívicos em certa medida exógenos à sua concepção de mundo: valores como "humanidade" e "nacionalidade", por exemplo. Além disso, as tradições culturais destes grupos muitas vezes continuaram sendo depreciadas como elementos relacionados à sua suposta situação de atraso: a referência às práticas supersticiosas e mágicas, por exemplo.

Examinando a produção teórica de Vasconcelos e os documentos editados à época em que ele esteve à frente da Secretaria, chama muito à atenção a ausência de referências ao trabalho que Manuel Gamio desenvolveu desde 1917 até 1924 - mesmo que houvesse tantos pontos de contato. Parece que, entre a geração literária e ensaística do Ateneo e o campo da Antropologia que começava a ser constituído no México, uma barreira se colocava. Claude Fell, mais uma vez, lança alguma luz sobre as razões desta minha impressão:

Entre la Secretaría de Educación Pública y la Dirección de Antropología, entre José Vasconcelos y Manuel Gamio, las relaciones no son buenas, y ambos organismos, en lugar de coordinar sus actividades, aplican políticas paralelas que se inspiran, sin confesarlo, la una en la otra. La Dirección de Antropología evidentemente resiente la falta de créditos y de medios, y Gamio se ve obligado a defenderla contra las "veleidades anexionistas" de la Universidad de México. (FELL, 1989, p. 216)

Gamio atribuiria o fracasso da política indigenista no México, em seus diversos aspectos, justamente à falta de ações de base realmente científica para a compreensão da

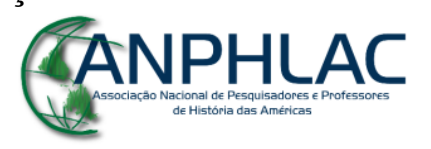

Revista Eletrônica da ANPHLAC, ISSN 1679-1061, №. 23, p. 82-118, Jul./Dez., 2017.

http://revista.anphlac.org.br 
estrutura e dos problemas dos grupos indígenas. De fato, ainda que a atuação de Vasconcelos à frente da SEP tenha sido a primeira a conseguir dar às propostas de educação da população indígena um alcance nacional, sua concepção girava em torno da associação da educação com a ideia de uma "missão evangelizadora", muito mais do que com a de um trabalho de pesquisa científica. Não por acaso, uma das figuras mais importantes no projeto de educação indígena/rural desenvolvido pela SEP, e pelo seu Departamento de Educação e Cultura Indígena, foi justamente a do "maestro misionero", e as instituições mais célebres que foram criadas foram as "missões culturais".

Como já vimos, o informe de Abraham Arellano de agosto de 1921 denunciava o fracasso das escolas rudimentares. Tais instituições eram conduzidas pelos chamados “maestros ambulantes", que deveriam, sobretudo, recrutar jovens com rudimentos da educação primária para trabalharem como educadores locais, após um trabalho de formação de três meses. O programa desenvolvido pelo Departamento de Cultura Indígena envolvia, não mais os maestros ambulantes, mas já os seus sucessores, os maestros misioneros.

O sistema de educação rural estabelecido foi planejado a partir da atuação dos misioneros, supervisionando os maestros rurales residentes e, ao mesmo tempo, realizando relatórios, informes e estatísticas regularmente enviadas à SEP, a fim de que se compreendessem melhor as realidades das distintas regiões do México (FELL, 1989, p. 220-221). Para Ernesto Meneses Morales, trocava-se um modelo verbalista, restrito à sala de aula e alheio à realidade concreta dos camponeses, por um sistema de educação inspirado na tradição missionária que se pautava no ensino da agricultura e de técnicas artesanais (MORALES, 1983, p. 325).

Tal projeto de investigação acerca da realidade rural nacional parece apresentar uma grande diferença em relação àquele levado a cabo pela Direção de Antropologia: as estatísticas e os relatórios elaborados pelos misioneros deveriam se debruçar, sobretudo, sobre a situação material dos grupos indígenas, suas condições econômicas, os potenciais produtivos das regiões exploradas, as atividades que poderiam ser fomentadas e os profissionais necessários para tanto - sem ter como objetivo a percepção do funcionamento interno destas próprias sociedades, em sua diversidade, e muito menos a garantia de qualquer preservação das culturas locais.

\section{GANPHLAC}

Revista Eletrônica da ANPHLAC, ISSN 1679-1061, №. 23, p. 82-118, Jul./Dez., 2017.

http://revista.anphlac.org.br 
A atuação dos misioneros possuía um viés, em grande medida, economicista, em que pesem os esforços no sentido de se promover as manifestações artísticas e culturais de cada região. Além disso, o papel fundamental de alfabetizar o índio em espanhol, e de promover sua educação cívica, tinha como objetivo uma integração à nação que passava, sobretudo, pela integração dos mercados e da produção. Isso ajudava a corroborar a visão monolítica que se tinha a respeito destas sociedades, caracterizandoas como grupos genericamente "indígenas", ou, mais genericamente ainda, "campesinos".

A gestão do Departamento de Educação e Cultura Indígena ficou, num primeiro momento, a cargo de Lauro Caloca, um dos grandes defensores da educação rural no país. Entretanto, deve-se destacar que diversos foram os planejadores das políticas de educação rural neste momento, tanto dentro da SEP quanto entre os deputados - que debatiam estas questões como questões do mais profundo interesse nacional - e na imprensa. Nesse sentido, compreende-se não apenas a própria criação do departamento provisional, contrariando a vontade de Vasconcelos, bem como o fato de que, muito brevemente, seria exigido por este departamento que todos os professores atuantes na educação indígena falassem as línguas autóctones - iniciativa a que Vasconcelos também não era, a princípio, favorável.

Como em outras áreas de atuação da SEP, no caso da educação indígena, um dos problemas mais graves encontrados foi a falta de pessoal capacitado. O que havia sido sugerido pelos deputados em janeiro de 1922, quando da criação do Departamento de Educação e Cultura Indígena, era que houvesse cem maestros misioneros e cem maestros rurales residentes para que se iniciasse o programa aprovado. Em fevereiro de 1922, haviam sido nomeados 77 misioneros (distribuídos, sobretudo, pelos estados com maior concentração de população indígena), mas apenas 13 residentes - que eram aqueles que, mais diretamente, lidavam com as populações locais no esforço educativo (FELL, 1989, p. 222). Meneses Morales destaca que, no treinamento dos residentes, realizado pelos misioneros, havia diversas falhas:

Se insistió en que el maestro [misionero] fuera un buen maestro y hábil expositor sin establecer un procedimiento para evaluar estas destrezas. Además, se esperaba que los maestros [misioneros], egresados de las normales urbanas, enseñaran agricultura e higiene relacionadas con el campo, desprovistos como estaban de preparación técnica o práctica en ese aspecto.

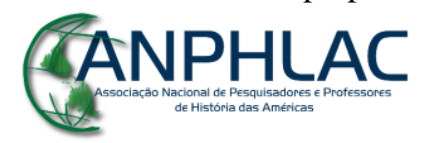

Revista Eletrônica da ANPHLAC, ISSN 1679-1061, №. 23, p. 82-118, Jul./Dez., 2017.

http://revista.anphlac.org.br 


\begin{abstract}
Vasconcelos ordenaba a sus misioneros enseñar a los maestros rurales a instruir a sus propios alumnos en la misma forma en que se les enseñaba a aquéllos, sin percatarse de que, ocupado el estudiante en adquirir el dominio de un contenido, encontraría difícil atender a las técnicas pedagógicas de los instructores. Olvidaba también Vasconcelos que los maestros rurales no habían asistido a ningún curso de metodología o teoría educativa que los habilitara para discernir los principios pedagógicos específicos. (MORALES, 1983, p. 324)
\end{abstract}

O fato é que, levando-se em consideração que quase tudo estava por fazer em um país de enormes proporções, torna-se inteligível o enfoque direcionado muito mais para o caráter quantitativo da ação educadora do que para o qualitativo. Mesmo assim, a questão da falta de professores residentes era tão séria que, em junho de 1922, autorizou-se aos misioneros que dividissem o salário de um residente entre vários "monitores" - geralmente moradores locais que haviam acabado de concluir seus estudos primários. Em informe do Departamento de Educação e Cultura Indígena de fevereiro de 1923, afirmava-se o número de 17.925 alunos inscritos, ao qual correspondia a quantidade de 85 maestros rurales residentes e 314 monitores (FELL, 1989, p. 224). Frente a esta situação, foram constantes as solicitações de que se aumentasse o número de misioneros e de residentes em todo o país.

Na sessão de 16 de dezembro de 1922 do Congresso, em que se discutiria o orçamento destinado à educação, várias propostas foram feitas nesse sentido, algumas chegando a propor a contratação de 5 mil maestros misioneros. Após uma intervenção da comissão dos deputados encarregada das questões educacionais salientar as reduções orçamentárias sofridas, e a voracidade do exército no consumo de recursos - além de sugerir que, dos cem misioneros que estariam ativos, apenas 20 ou 30 cumpririam com suas funções -, o próprio Vasconcelos conseguiu que se aprovasse o número mais realista de 200 misioneros (a um salário de 10 pesos diários) e 3.000 residentes (a um salário de 3,50 ao dia), bem como um orçamento para compra de material.

Como se pode perceber, era um número muitíssimo restrito para uma atuação de nível nacional. Além disso, assim como havia sido registrado no caso dos professores honorários que conduziam a Campanha contra o Analfabetismo, as hostilidades por parte de grandes terratenientes ou autoridades locais eram constantes, bem como a falta de interesse na educação por parte de muitos indígenas. Os ambientes escolares, na maior parte dos casos, também se encontravam em péssimas condições. Além destas

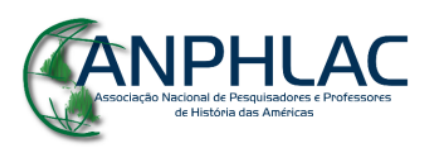

Revista Eletrônica da ANPHLAC, ISSN 1679-1061, №. 23, p. 82-118, Jul./Dez., 2017.

http://revista.anphlac.org.br 
dificuldades em comum, vale lembrar que a educação indígena e a Campanha contra o Analfabetismo eram iniciativas que se tocavam. Também cabia aos maestros misioneros recrutar professores honorários para trabalhar na Campanha.

Nas mesmas sessões de dezembro de 1922 que discutiram o orçamento da educação, aprovou-se a destinação de cem mil pesos para a implementação de centros culturais indígenas - idealizados a partir do mesmo modelo que dera origem aos centros culturais urbanos, voltados para os trabalhadores. Tal projeto daria origem às chamadas Casas do Povo, que teriam seu estatuto publicado em abril de 1923 pelo novo chefe do Departamento de Educação e Cultura Indígena, Enrique Corona.

Entre outras coisas, determinava-se que a alfabetização, ainda que importante, não era a atividade primordial das Casas do Povo, já que a formação cívica e as instruções técnicas que dariam origem ao progresso econômico seriam urgentes. Além disso, tais espaços perpassariam todos os elementos da vida da população local, funcionando a partir do modelo de cooperativa, de modo a garantir a autossuficiência econômica da população - algo que já vinha sendo feito nos centros culturais diurnos nas cidades (FELL, 1989, p. 239-240).

É claro que, em meio às discussões sobre a autonomia econômica das populações indígenas - e aqui se repete a tendência de se compreender o índio como um simples camponês -, a questão do acesso à terra aparecia como um problema fundamental. Em declaração ao jornal Excélsior, de 22 de março de 1923, Enrique Corona afirmou que qualquer política educativa seria inútil se não viesse acompanhada de uma política de distribuição de terras e de criação de infraestrutura (FELL, 1989, p. 238). A questão da reforma agrária era, de fato, uma demanda fundamental do período de insurreição, assegurada pela Constituição de 1917 e associada diretamente ao caráter "revolucionário" dos governos que se estabeleceriam a partir de 1920 - ainda que uma ampla reforma agrária só tenha sido de fato realizada nos anos 1930. Além disso, o Departamento de Educação e Cultura Indígena realizou uma política de combate aos despejos, ao trabalho forçado e à escravidão por dívidas, tão presentes no meio rural caudilhesco do México (FELL, 1989, p. 252).

Neste momento, Vasconcelos já se mostrava mais interessado e engajado no Departamento de Educação e Cultura Indígena, chegando a fazer declarações laudatórias a seu respeito em jornais. No ano de 1923, diversas circulares emitidas pelo

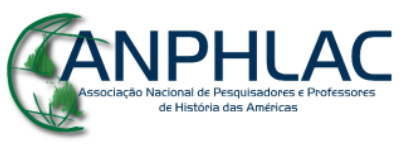

Revista Eletrônica da ANPHLAC, ISSN 1679-1061, №. 23, p. 82-118, Jul./Dez., 2017.

http://revista.anphlac.org.br 
secretário, algumas vezes acompanhado de Enrique Corona, com a intenção de instruir o trabalho relativo às Casas do Povo, confirmavam as tendências do modelo educativo adotado até então e apresentavam um Vasconcelos surpreendentemente muito mais próximo do ideal indigenista de Manuel Gamio. Eivado de uma nova concepção do magistério, que aproximava o misionero do professor-antropólogo de Gamio, afirmava que os educadores deveriam buscar valorizar as formas de conhecimento indígenas e, inclusive, aprender com elas. Orientava, desta forma, que eles deveriam tentar

Penetrar la mentalidad de sus educandos, no sólo para influir sobre ellos con mayor eficacia, sino para también descubrir la porción de verdad que sin duda se conserva en los usos y conocimientos de los indígenas. (FELL, 1989, p. 243)

Os elementos a serem aprendidos com os índios englobariam seu conhecimento de plantas medicinais e seu entendimento do meio ambiente, suas crenças e costumes, e mesmo elementos "equivocados" que pudessem levar a uma compreensão da alma humana em seus erros e acertos. Desta forma, o contato entre o misionero e o indígena seria marcado pelo intercâmbio e pelo aprendizado mútuo, não podendo ser reduzido à tutela do "civilizador" sobre o "bárbaro" (dualismo do qual Vasconcelos sempre se serviu e do qual continuaria a se servir mais tarde). Neste ponto, seu argumento se aproximava quase do enciclopedismo:

\footnotetext{
es parte de los deberes del maestro dar a conocer al mundo el alma de los indígenas, de igual suerte que debe poner al indígena en comunicación con la ciencia acumulada por el resto de la humanidad durante el curso de los siglos. [...] bien penetrado de las diferencias de la cultura que va a propagar, procurará el maestro descubrir en el medio indígena todo lo que sirva para ir llenando el vacío de la ignorancia universal, la avidez clamorosa de la conciencia humana. (FELL, 1989, p. 244)
}

Dados presentes em alguns dos Boletines de la SEP e em um informe do presidente Obregón de 1924 nos revelam as informações presentes na tabela abaixo, relativas às escolas rurais/Casas do Povo, bem como aos alunos que as frequentavam e aos professores (misioneros e residentes) que lecionavam nelas.

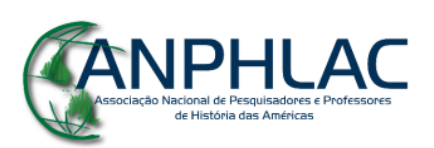

Revista Eletrônica da ANPHLAC, ISSN 1679-1061, №. 23, p. 82-118, Jul./Dez., 2017.

http://revista.anphlac.org.br 
Tabela 2: Números relativos à educação indígena e rural nos anos de 1922, 1923 e $1924^{5}$

1922

\begin{tabular}{l|r|r|r}
\hline Maestros Misioneros & & 101 & 48 \\
\hline Maestros Rurales & & 904 & 1.146 \\
\hline Total de professores & 314 & 1.005 & 1.194 \\
\hline Alunos & 17.925 & 49.640 & 65.000 \\
\hline Escolas/Casas do Povo & 309 & 904 & 1.039 \\
\cline { 2 - 4 } & & &
\end{tabular}

Percebemos que o número de alunos e de escolas cresceu progressivamente durante estes três anos. Em relação aos professores, não temos dados comparativos entre misioneros e residentes relativos a 1922, mas entre 1923 e 1924 percebemos uma redução radical do número de maestros misioneros (de mais da metade) acompanhada de um crescimento significativo no número de maestros rurales - que recebiam salários menores e atuavam mais diretamente junto aos grupos de camponeses e indígenas, sendo, muitas vezes, oriundos destas comunidades.

O que mais chama a atenção, de todo modo, é que, mesmo se considerarmos as quantidades máximas de maestros misioneros, maestros rurales, alunos e escolas, tratase de um quantitativo muitíssimo limitado. Com base no Boletín de la SEP II, número 5-6, de 1924, Claude Fell apresenta números relativos ao crescimento geral da educação primária entre os anos de 1920 e de 1923, números estes que represento na próxima tabela. Nela, optei por privilegiar as instituições públicas de ensino, inserindo informações relativas às instituições privadas apenas no ano de 1923, para que possamos ter uma noção da discrepância entre estes dois tipos de estabelecimentos escolares. Devemos ter em mente, no entanto, que a atuação das instituições particulares se encontrava, evidentemente, fora da área de atuação da SEP.

\footnotetext{
${ }^{5}$ Esta tabela é uma adaptação daquelas que Claude Fell organiza em FELL, 1989, p. $248-249$ e p. 251, complementadas por alguns dados apresentados em FELL, 1989, p. 250. A seu respeito, alguns elementos devem ser levados em consideração: os dados relativos ao ano de 1922 vêm do Boletín de la SEP I, número 3, de janeiro de 1923, e os relativos ao ano de 1923 vêm do Boletín de la SEP III, número 5-6, de janeiro de 1924. Para o ano de 1924, utilizaram-se os dados de um informe do presidente Obregón de $1^{\circ}$ de setembro de 1924. No Boletín de 1922, maestros misioneros e maestros rurales são computados conjuntamente. Além disso, este Boletín se refere apenas a "escolas dependentes do departamento de cultura indígena", dentre as quais devem ser consideradas as Casas do Povo eventualmente criadas. O informe presidencial de 1924 só faz referência às Casas do Povo.
}

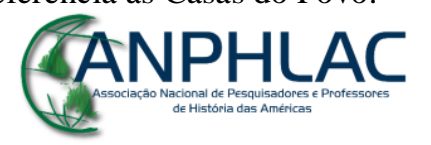

Revista Eletrônica da ANPHLAC, ISSN 1679-1061, №. 23, p. 82-118, Jul./Dez., 2017.

http://revista.anphlac.org.br 
Tabela 3: Números relativos à educação primária nos anos de 1920, 1921, 1922 e 1923 6

\begin{tabular}{|c|c|c|c|c|c|}
\hline & 1920 & 1921 & 1922 & $\begin{array}{l}1923 \\
\text { (oficiais) }\end{array}$ & $\begin{array}{l}1923 \\
\text { (particulares) }\end{array}$ \\
\hline Professores & 17.206 & 18.992 & 20.639 & 26.065 & 4.845 \\
\hline Alunos & 679.897 & 757.349 & 901.199 & 1.044 .539 & 142.868 \\
\hline Escolas & 8.161 & 9.547 & 10.544 & 13.847 & 1.744 \\
\hline
\end{tabular}

A comparação entre o crescimento da educação primária em geral e a realidade específica da educação indígena e rural evidencia que, apesar da dimensão que a discussão da expansão da educação alcançou neste período, a discrepância entre a educação oferecida nos centros urbanos e nas áreas mais isoladas do país continuou imensa. O censo de 1921 considerava as áreas com mais de 2.500 habitantes como áreas urbanas, e aquelas com uma quantidade inferior de moradores como áreas rurais. Segundo este critério (problemático, por apenas levar em conta o número de habitantes), 68,8\% da população era rural em 1921 (INSTITUTO NACIONAL, 1996, p. 104). Entretanto, o número de alunos contemplados pela ação do Departamento de Educação e Cultura Indígena, mesmo no "ano feliz de 1923", como o chamava Vasconcelos, era quase um terço do número de alunos atendidos apenas pelas instituições privadas de educação primária no mesmo ano. O número de escolas rurais, no mesmo período, também era pouco mais do que a metade da quantidade somente das escolas primárias particulares.

Em fala no Congresso de setembro de 1923, o deputado agrarista José Gálvez afirmou o fracasso da atuação dos maestros misioneros. Para ele, tal fracasso tinha diversos motivos, da falta de preparo à resistência dos professores, passando pela vinculação de muitos misioneros a influências políticas locais e mesmo pela degeneração de seus hábitos e pela entrega aos vícios - elementos os quais o Departamento de Educação e Cultura Indígena teria dificuldade de controlar. A partir destas críticas, Gálvez elaborou o projeto das chamadas Missões Culturais - projeto que logo ganharia o aval de Gabriela Mistral (em correspondência do Chile) e do próprio Vasconcelos, que promulgou um decreto em 17 de outubro de 1923 em que afirmava: "En vista de las ventajas que reporta el proyecto del C. diputado José Gálvez relativo a

\footnotetext{
${ }^{6}$ Esta tabela é uma adaptação da que Claude Fell organiza em FELL, 1989, p. 166.

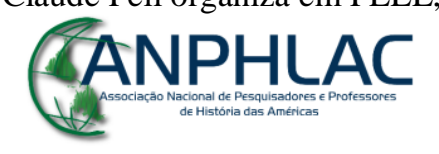

Revista Eletrônica da ANPHLAC, ISSN 1679-1061, №. 23, p. 82-118, Jul./Dez., 2017.

http://revista.anphlac.org.br
} 
la actuación de los maestros misioneros, he tenido a bien disponer que esta Secretaría haga suyo el citado proyecto", determinando ainda que este decreto deveria ser impresso e distribuído nas dependências da SEP (MORALES, 1983, p. 328).

O primeiro trabalho dos misioneros nas Missões Culturais (enviadas às áreas de maior concentração indígena) deveria ser próximo ao do professor-antropólogo de que falava Gamio, classificando e conhecendo as populações indígenas das várias áreas do México. Em seguida, seriam construídas, em cada região, uma escola, oficinas e locais de plantação, dotados de infraestrutura para operar a educação integral que já era almejada pela SEP havia algum tempo. Como já foi dito, entretanto, em fins de 1923 e inícios de 1924, a situação da Secretaria de Educação Pública mudou muito. O orçamento diminuiu consideravelmente e a conjuntura do país não permitiu um grande desenvolvimento do projeto das Missões Culturais, que ganhariam especial impulso no governo de Calles, sucessor de Obregón, com os secretários de educação José M. Puig Casauranc e, a partir de 1928, Moisés Sáenz.

\section{Triunfará Quetzalcóatl!}

O período que Vasconcelos passou à frente da Universidade Nacional do México, a partir de 1920, e os quase três anos em que permaneceu à frente da SEP (de outubro de 1921 a julho de 1924), representaram, de fato, o primeiro esforço sistemático de federalização da educação no país, com foco não apenas nos espaços urbanos, mas, de maneira enfática, na imensa área rural que constituía a maior parte do México. Tal esforço se iniciou no governo interino de De La Huerta, mas se desenvolveu em sua extensão máxima durante a gestão de seu aliado Obregón (ambos, junto com Calles, membros do chamado "triângulo sonorense").

No entanto, o primeiro grande desafio ao governo Obregón veio justamente com o rompimento deste triângulo. Ao longo do ano de 1923, tornava-se cada vez mais evidente o apoio que Obregón daria a Calles (então seu secretário de governo) na sucessão presidencial, o que descontentava De la Huerta (que assumira como secretário da fazenda). O conflito aberto veio com a rebelião delahuertista, em dezembro de 1923, que contou com o apoio de cerca de $40 \%$ do exército. A rebelião foi contida ao longo do

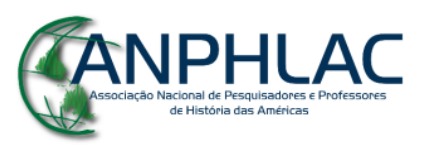

Revista Eletrônica da ANPHLAC, ISSN 1679-1061, №. 23, p. 82-118, Jul./Dez., 2017.

http://revista.anphlac.org.br 
ano de 1924, mas as constantes ameaças aos líderes da oposição a Obregón, bem como o assassinato do senador oposicionista Field Jurado, ajudaram a desgastar a imagem do presidente.

À ocasião do assassinato de Field Jurado, Vasconcelos entregou um pedido de renúncia ao seu cargo na SEP, o qual Obregón o convenceu a retirar. O pedido, entretanto, não vinha apenas como reação ao assassinato perpetrado com a conivência de Obregón; a relação de Vasconcelos com o presidente já vinha sofrendo com a crescente dificuldade que o secretário tinha em implementar as suas propostas, mesmo com a aprovação de orçamentos relativamente grandes, em comparação com a realidade do país. A rebelião de De la Huerta, por outro lado, ajudou a minar ainda mais os recursos públicos destinados à educação, tamanha a proporção que alcançou. Finalmente, em $1^{\text {o }}$ de julho de 1924, Vasconcelos apresentou mais uma vez sua renúncia a Obregón, que desta vez a aceitou. Oficialmente, Vasconcelos preparava sua candidatura ao governo de Oaxaca, mas na prática sua presença à frente da SEP já se tornara insustentável.

O legado educacional que deixou, como vimos, foi marcado pelo pioneirismo da iniciativa, mais do que pela originalidade das propostas (que encontram antecedentes nos projetos elaborados nas duas primeiras décadas do século XX). Nos centros urbanos e, sobretudo, no Distrito Federal, as mudanças foram perceptíveis - tanto no que diz respeito propriamente às políticas educacionais, quanto ao incentivo das artes plásticas, das publicações editoriais, da música e dos esportes. Entretanto, no que tange à atuação de programas de maior extensão geográfica, como a Campanha contra o Analfabetismo e as iniciativas do Departamento de Educação e Cultura Indígena, vemos que os resultados concretos foram bastante modestos. $\mathrm{O}$ alcance que estas iniciativas tiveram nas discussões parlamentares e na imprensa por vezes mascara as limitações reais das possibilidades de atuação da SEP.

A grande particularidade da forma como Vasconcelos pensou a educação durante sua gestão partia, em larga medida, da forma como suas concepções estéticas e espirituais impactaram seus projetos. Vastos recursos foram empregados no financiamento de grandes monumentos artísticos que deveriam simbolizar esteticamente a direção do progresso que Vasconcelos acreditava estar impingindo ao México. Milhares de cópias dos Clásicos foram distribuídas por todo o país, para que levassem a

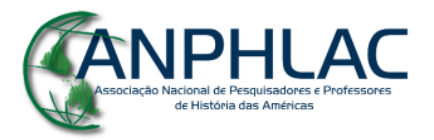

Revista Eletrônica da ANPHLAC, ISSN 1679-1061, №. 23, p. 82-118, Jul./Dez., 2017.

http://revista.anphlac.org.br 
ilustração ao povo. Grandes obras, como o Estádio Nacional, poderiam abrigar jogos, peças teatrais ou concertos de grande magnitude. Mas o povo mexicano talvez não estivesse preparado para o gozo estético que Vasconcelos tanto almejava. De maneira ácida, Enrique Krauze comenta que

A pesar de que Vasconcelos fue un activo maderista de primera hora [...] la historia y la sociedad mexicanas no eran para él, como tampoco para sus amigos, realidades visibles. [...] De una u otra forma, todo el Ateneo se exilia. [...] Vivian en Grecia, no en México. (KRAUZE, 2000, p. 933)

O comentário de Krauze talvez infira um julgamento duro demais à obra de Vasconcelos. Havia muita consciência social em seus projetos e na sua realização, ainda que uma confiança talvez muito grande no destino de progresso do México o tenha impedido de ver o risco das apostas que fazia. Da mesma forma, a ênfase na educação como uma missão, uma atividade fundamentalmente abnegada e espiritual, mais do que pedagógica, ou mesmo (como no caso do projeto de educação indígena que Gamio propunha) antropológica, certamente fez com que muitas das iniciativas não tenham logrado resultados satisfatórios.

De maneira profética, no discurso que Vasconcelos realizou em homenagem ao dia do professor em maio de 1924, discurso que ele sabia que era a sua despedida da Secretaria e que, de fato, foi o seu último à frente da SEP, ele evocou mais uma vez a figura de Quetzalcóatl como a gritar que ele mesmo, José Vasconcelos, não desistia:

\footnotetext{
En efecto, algo hay en el ambiente nacional y en la conciencia de los maestros mismos que hace en estos momentos que no parezcan del todo, a pesar de la analogía aparente, a los instantes de amargura en que el alma de Quetzalcóatl mira que su obra se pierde en los ríos de sangre y desilusionando se ausenta. Hoy la conciencia colectiva sabrá inspirarse en Quetzalcóatl, cuya alma se multiplica en cada uno de los maestros. ¡Quetzalcóatl, el principio de la civilización, el dios constructor, triunfará de Huitzilopochtli, el demonio de la violencia y el mal, que tantos siglos lleva de insolente y destructor poderío! ¡Triunfará hoy o mañana, pero es el maestro quien tiene en sus manos la bandera inmortal! (VASCONCELOS, 2009d, p. 193)
}

Triunfará Quetzalcóatl! Enquanto o projeto que Vasconcelos havia sonhado parecia ruir, restava ainda a fé em seu discurso. A fé de que seu legado seria recuperado

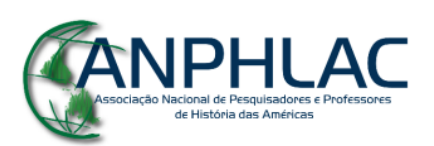

Revista Eletrônica da ANPHLAC, ISSN 1679-1061, №. 23, p. 82-118, Jul./Dez., 2017.

http://revista.anphlac.org.br 
e frutificaria no futuro. E, neste ponto, não estava equivocado. Como afirma Regina Crespo:

\begin{abstract}
Podemos dizer que, a partir da saída de Vasconcelos da SEP, os ministros que o sucederam tiveram direta ou indiretamente que dialogar ou discutir com o plano que ele deixou. Em termos gerais, a questão específica da educação rural e indígena continuou sendo pautada pelos preceitos integracionistas, seja na linha missionária cristã, inaugurada por Vasconcelos, seja na linha da política indigenista defendida por Gamio e daquela levada a cabo no âmbito da própria SEP, já sob as ordens de Puig Casauranc, na presidência de Calles, pelo subsecretário Moisés Sáenz. (CRESPO, 2016, p. 139)
\end{abstract}

Vasconcelos acreditava na educação como quem acredita em uma missão religiosa, de inspiração divina. Por isso mesmo, chama a atenção a ênfase que ele dá à alegoria da luta de Quetzalcóatl contra Huitzilopochtli como representação da oposição "civilização x barbárie". Recorrer a uma imagem da tradição mexica para ilustrar uma visão da educação inspirada no missionarismo colonial parece, a princípio, contraditório.

Entretanto, esta escolha talvez seja um dos retratos mais claros daquilo em que Vasconcelos acreditava. Enquanto homem público e enquanto intelectual, ele jamais afirmou que a tradição indígena, como um todo, deveria desaparecer. Por isso mesmo, patrocinou festas populares, danças típicas, e em seu mais famoso ensaio, La raza cósmica, afirmou que o índio teria muito em que contribuir na formação de uma raça universal, a "raça cósmica", na América Latina. Mas a contribuição do índio dificilmente era concebida para além de uma idealização de caráter folclórico (as circulares emitidas em 1923 constituem uma notável exceção). As manifestações artísticas poderiam e deveriam manter a cor local, mas a inspiração fundamental que levaria ao progresso viria da civilização europeia, particularmente da civilização latina hispânica, sobretudo.

Ironicamente, dentro da alegoria de Vasconcelos (completamente estranha à cosmologia mexica), Quetzalcóatl assumia o papel positivo do educador missionário europeu, enquanto Huitzilopochtli (a mais cultuada divindade dos mexicas) encarnava o papel negativo da ignorância que era associada à própria população indígena degenerada. O universalismo do pensamento filosófico e estético de Vasconcelos se revelava, tanto no discurso como na prática, profundamente excludente. As limitações

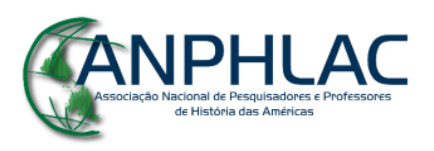

Revista Eletrônica da ANPHLAC, ISSN 1679-1061, №. 23, p. 82-118, Jul./Dez., 2017.

http://revista.anphlac.org.br 
concretas de seu programa educacional à frente da SEP, desta forma, devem também ser compreendidas à luz da impossibilidade de se conceber a autonomia indígena em um esquema conceitual que via como natural o caminho através do qual a bipolaridade "civilização x barbárie" terminaria com a derrota da segunda em função da primeira: a vitória de Quetzalcóatl sobre Huitzilopochtli, a completa incorporação do indígena pela sociedade mexicana.

\section{Referências bibliográficas}

ASCENSO, João Gabriel da Silva. A redenção cósmica do mestiço: inversão semântica do conceito de raça na Raza cósmica de José Vasconcelos. Estudos Históricos, Rio de Janeiro, CPDOC-FGV, v. 26, n. 52, 2013.

BATALLA, Guillermo Bonfil. México profundo: una civilización negada. México: SEP, 1987.

BORDIN, Reginaldo Aliçandro. Mito e religião na sociedade asteca. Revista CESUMAR - Ciências Humanas e Sociais Aplicadas, Maringá, v. 8, n. 1, 2003.

CRESPO, Regina. O projeto educativo de José Vasconcelos no México pósrevolucionário: nacionalismo e modernidade. Intellèctus, Rio de Janeiro, UERJ, v. 15, n. 2, 2016.

FELL, Claude. Cronología. In: VASCONCELOS, José. Ulises criollo. Edição crítica coordenada por Claude Fell. Madri/Barcelona/Havana/Lisboa/Paris/México/Buenos Aires/São Paulo/Lima/Guatemala/San José: ALLCA XX, 2000.

José Vasconcelos: los años del águila (1920-1925), educación, cultura e iberoamericanismo en el México postrevolucionario. México: UNAM, 1989.

GAMIO, Manuel. Forjando patria. México: Porrúa, 2006.

INSTITUTO NACIONAL de Estadística, Geografía e Informática (México). Estados Unidos Mexicanos: cien años de censos de población. Aguascalientes: INEGI, 1996. Disponível em: http://www.inegi.org.mx/prod_serv/contenidos/espanol/bvinegi/product os/integracion/pais/historicas2/cienanos/EUMCIENI.pdf Acesso em: 24 de abril de 2015.

KRAUZE, Enrique. Pasión y contemplación en Vasconcelos. In: VASCONCELOS, José. Ulises criollo. Edição crítica coordenada por Claude Fell. Madri/Barcelona

\section{CANPHLAC}

Revista Eletrônica da ANPHLAC, ISSN 1679-1061, №. 23, p. 82-118, Jul./Dez., 2017.

http://revista.anphlac.org.br 
/Havana/Lisboa/Paris/México/Buenos Aires/São Paulo/Lima/Guatemala/San José: ALLCA XX, 2000.

MEYER Jr., Jean. O México: revolução e reconstrução nos anos de 1920. In: BETHELL, Leslie (Org.). História da América Latina, volume V: de 1870 a 1930. São Paulo/Brasília: Universidade de São Paulo/Imprensa Oficial do Estado (SP)/Fundação Alexandre de Gusmão, 2001.

MOCTEZUMA, Eduardo Matos. Quetzalcóatl en la historia y en la leyenda. México desconocido. Disponível em: http://www.mexicodesconocido.com.mx/quetzalcoatl-enla-historia-y-en-la-leyendas.html Acesso em: 26 de janeiro de 2015.

MONSIVÁIS, Carlos. Notas sobre la cultura mexicana en el siglo XX. In: El Colegio de México (Org.). Historia General de México, tomo IV. México: El Colegio de México, 1976.

MONTFORT, Ricardo Pérez. Un nacionalismo sin nación aparente (la fabricación de lo "típico" mexicano 1920-1950). Política y Cultura, Universidad Autónoma Metropolitana, Xochimilco, México, n. 12, 1999.

MORALES, Ernesto Meneses. Tendencias educativas oficiales en México, volume 2: 1911-1934. México: Porrúa, 1983.

MOTTA, Romilda Costa. José Vasconcelos: as Memórias de um "profeta rejeitado". Dissertação de mestrado apresentada ao Programa de Pós-graduação em História Social da USP. São Paulo, 2010.

SANTOS JUNIOR, Valdir Donizete dos. Mestiçagem e questão indígena no Porfiriato: identidade e alteridade nas obras de Justo Sierra. Revista Eletrônica da ANPHLAC, São Paulo, n. 14, 2013. Disponível em: http://www.revistas.fflch.usp.br/anphlac/article /view/1232 Acesso em: 19 de fevereiro de 2015.

VASCONCELOS, José. Carta abierta a los obreros del estado de Jalisco (1921). In: Antología de textos sobre educación. México: Trillas, 2009a.

. Conferencia leída en el Continental Memorial Hall de Washington (1922). In: . Antología de textos sobre educación. México: Trillas, 2009 b.

Discurso con motivo de la tomada de posesión del cargo de Rector de la Universidad Nacional de México (1920). Antología de textos sobre educación. Introdução. México: Trillas, 2009c.

Discurso pronunciado el Día del Maestro (1924). In: Antología de textos sobre educación. México: Trillas, 2009d.

\section{GANPHLAC}

Revista Eletrônica da ANPHLAC, ISSN 1679-1061, №. 23, p. 82-118, Jul./Dez., 2017.

http://revista.anphlac.org.br 
El desastre. In:

Memorias, 2: El desastre/El proconsulado. México:

Fondo de Cultura Económica, 1982a.

Introdução. In:

Antología de textos sobre educación. Introdução.

México: Trillas, 2009e.

La educación pública (Indología). In: Antología de textos sobre educación. México: Trillas, $2009 f$.

La Raza Cósmica. México: Porrúa, 2010.

La tormenta. In: Memorias, 1: Ulises criollo / La tormenta. México: Fondo de Cultura Económica, 1982b. 